\title{
MANAJEMEN BIROKRASI DALAM PENGEMBANGAN KARIR DAN PROMISI JABATAN DI DINAS KESEHATAN KABUPATEN POLEWALI MANDAR
}

\author{
Abd Khalaik', Muhammad Awarih ${ }^{2}$ \\ ${ }_{1}^{1}$ Prodi Ilmu Pemerintahan, Fakultas Ilmu Sosial dan Ilmu Pemerintahan \\ Universitas Al Asyariah Mandar \\ Email: Khalikmandar@gmail.com \\ ${ }_{3}^{3}$ Prodi Ilmu Pemerintahan, Fakultas Ilmu Sosial dan Ilmu Pemerintahan \\ Universitas Al Asyariah Mandar \\ Email: azwarihaco@gmail.com
}

\section{ABSTRACT}

This study aims to describe and analyze the influence of career development and promotion at the Polewali Mandar District Health Office. Data collection techniques through observation, interviews, and image documentation. The results showed that career development as the empowerment of ASN in the Polewali Mandar Health Service was in accordance with Law Number 5 of 2014 concerning ASN. Employees pay attention to discipline, education levels and recommendations from local agencies. Its management has been running quite well based on the applicable regulations while still prioritizing the discipline and behavior of ASN even though it is not yet optimal.

\section{ABSTRAK}

Penelitian ini bertujuan untuk menggambarkan dan menganalisa pengaruh perkembangan karir dan promosi jabatan di Dinas Kesehatan Kabupaten Polewali Mandar. Tehnik pengumpulan data melalui observasi, wawancara, dan dokumentasi gambar. Hasil penelitian menunjukkan bahwa pengembangan karir sebagai pemberdayaan ASN di Dinas Kesehatan Polewali Mandar, telah sesuai dengan Undang-undang Nomor 5 Tahun 2014 tentang ASN. Pegawainya memperhatikan kedisiplinan, jenjang pendidikan dan rekomendasi dari instansi setempat. Pengelolaannya telah berjalan dengan cukup baik berdasarkan peraturan yang berlaku dengan tetap mengedepankan kedisiplinaan dan prilaku ASN meski belum maksimal.

Kata Kunci: Regulasi, Pengembangan, Karir, Dinas Kesehatan. 


\section{PENDAHULUAN}

Mengembangkan kompetensi pegawai menjadi suatu kegiatan yang perlu dan khusus untuk tercapainya reformasi birokrasi. Upaya yang dilakukan oleh pemerintah dalam melaksanakan program ini adalah dengan memberikan atau mengadakan seminar, pelatihan, kursus sampai pertukaran pegawai negeri dengan pegawai swasta. Diharapkan dengan program ini terdapat kinerja baik yang ditunjukkan oleh pegawai dilingkungan Aparatur Sipil Negara (ASN).

Setiap pegawai memiliki hak yang sama untuk bisa mencapai jabatan tertentu jika kinerja yang dilakukan telah maksimal dan telah mendapatkan nilai yang objektif dari pemerintah atau kepala lembaga/instansi yang berkaitan. Sehingga bisa dilakasanakan promosi ke jabatan yang lebih tinggi. Kegiatan seperti ini dapat memaksimalkan kinerja pegawai ASN menjadi lebih baik.

Pegawai Negeri Sipil yang selanjutnya disingkat PNS adalah warga negara Indonesia yang memenuhi syarat tertentu, diangkat sebagai Pegawai Aparatur Sipil Negara secara tetap oleh pejabat pembina kepegawaian untuk menduduki jabatan pemerintahan. ASN terintegrasi mulai dari perencanaan, perekrutan, pengembangan karir, penggajian, sampai pemberhentian/pensiun. Pengembangan karir sangat penting bagi setiap orang, karena perkembangan karir adalah bentuk penghargaan bagi kinerjanya selama bekerja.

Jenjang karir profesional merupakan sistem untuk meningkatkan kinerja dan profesionalisme, sesuai dengan bidang pekerjaan melalui peningkatan kompetensi. Jenjang karir merupakan jalur mobilitas vertikal yang ditempuh melalui peningkatan kompetensi, dimana kompetensi tersebut diperoleh dari pendidikan formal berjenjang, pendidikan informal yang sesuai/relevan maupun pengalaman praktik klinis yang diakui. Dengan arti lain, jenjang karir merupakan jalur untuk peningkatan peran perawat profesional di sebuah institusi. Dalam penerapannya, jenjang karir memiliki kerangka waktu untuk pergerakan dari satu level ke level lain yang lebih tinggi dan dievaluasi berdasarkan penilaian kinerja.

Pengembangan sistem jenjang karir profesional bagi perawat dapat dibedakan antara tugas pekerjaan dan karir. Pekerjaan sebagai perawat diartikan sebagai suatu posisi atau jabatan yang diberikan/ditugaskan, serta ada keterikatan hubungan pertanggung jawaban dan kewenangan antara atasan dan bawahan, dan mendapatkan imbalan penghargaan berupa uang. Karir sebagai perawat diartikan sebagai suatu bidang kerja yang dipilih dan ditekuni oleh individu untuk dapat memenuhi kepuasan kerja individu melalui suatu sistem dan mekanisme peringkat, dan bertujuan untuk meningkatkan keberhasilan pekerjaan sehingga pada akhirnya akan memberikan kontribusi 
terhadap bidang profesi yang dipilihnya. Pemilihan karir dan meningkatkannya secara bertahap akan menjamin individu perawat dalam mempraktikkan bidang profesinya, karena karir merupakan investasi jangka panjang yang menghasilkan pengakuan dan penghargaan baik materi maupun non materi sesuai level karir perawat yang disandangnya. Komitmen terhadap karir, dapat dilihat dari sikap dan perilaku individu perawat terhadap profesinya serta motivasi untuk bekerja sesuai dengan karir yang telah dipilihnya. Dalam sistem jenjang karir profesional terdapat beberapa aspek yang saling berhubungan yaitu kinerja, orientasi profesional dan kepribadian yang baik.

Pengembangan karir pegawai negeri sipil pada pemerintahan tidak sama dengan pengembangan karir pada perusahaaan swasta. Pengembangan karir pegawai negeri sipil dinilai dengan beberapa indikator yaitu prestasi kerja, pelatihan (Diklat), pengalaman kerja, promosi dan kesempatan untuk tumbuh. Dibeberapa daerah pengembangan karir pegawai diukur dengan indikator yang berbeda-beda seperti penelitian yang dilakukan di bali oleh Jayanti (2012).

Data Badan Kepegawaian Negara menunjukkan saat ini terdapat hampir empat juta pegawai negeri sipil Kritik tentang rendahnya mutu pelayanan PNS selalu dikaitkan dengan profesionalisme semata. Padahal, tidak memadainya kualitas kerja PNS juga merupakan akibat tidak berimbangnya rasio antara jumlah PNS dengan para stakeholders-nya. PNS di Indonesia hanya 1,7 dari total jumlah masyarakat Indonesia. Terlepas dari pentingnya aspek jumlah, mengefisienkan jumlah PNS dipandang sebagai formula yang dapat diterapkan guna memastikan setiap PNS bekerja secara lebih serius berdasarkan posisi mereka.

PNS atau sering disebut birokrat, sesungguhnya adalah publik servant yang wajib memberikan pelayanan publik yang terbaik kepada masyarakat sebagai pelanggan. Salah satu bentuk motivasi yang dapat memacu seorang PNS bekerja lebih profesional, antara lain adalah adanya sistem pola karier yang jelas. Pola karier PNS adalah pola pembinaan pegawai yang menggambarkan alur perkembangan karier yang menunjukkan keterkaitan dan keserasian antara jabatan, pangkat, pendidikan dan pelatihan jabatan, kompetensi, serta masa jabatan sejak pengangkatan pertama dalam jabatan tertentu sampai dengan pensiun.

Pola karier PNS disusun oleh pejabat yang berwewenang sejak pengangkatan pertama sebagai CPNS/PNS/jabatan hingga mencapai batas usia pensiun. Hakikat pola karier PNS adalah lintasan perkembangan dan kemajuan pegawai dengan pola gerakan posisi pegawai baik secara horizontal maupun vertikal yang selalu mengarah pada tingkat atau jenjang posisi yang lebih tinggi. Ditegaskan dalam Undang-Undang Pokok-pokok Kepegawaian, 
PNS diangkat dalam jabatan dan pangkat, pada jabatan struktural dan jabatan fungsional. Jabatan adalah kedudukan yang menunjukkan tugas, tanggung jawab, wewenang, dan hak seseorang PNS dalam suatu satuan organisasi negara. Jabatan dalam lingkungan birokrasi pemerintah adalah jabatan karier.

Hal ini merupakan salah satu prinsip pengembangan karir yang sangat fundamental sifatnya. Salah satu cara meningkatkan kualitas pegawai yaitu melalui pengembangan karir yang direalisasikan melalui prestasi kerja, pelatihan (Diklat), pengalaman kerja, promosi dan kesempatan untuk tumbuh. Namun hal ini relatif tidak berjalan sebagaimana mestinya, tidak jarang hal ini menjadi topik hangat yang diperbincangkan. Berbagai kekeliruan dan penyimpangan mewarnai upayaupaya pemerintah dalam mengembangkan sumber daya manusianya seperti halnya promosi jabatan.

\section{METODE PENELITIAN}

Penelitian ini menggunakan pendekatan kualitatif, yakni suatu metode yang digunakan untuk meneliti objek alamiah dimana peneliti sebagai instrumen kunci. Pengambilan sampel sumber data dilakukan secara surposive, teknik pengumpulan dengan triagulasi. Analisi data bersifat induktif/kualitatif. Proses penelitian dimulai dengan menyusun asumsi dasar dan aturan berpikir yang akan digunakan dalam penelitian.

Penelitian dilakukan di BKPP dan Dinkes di Kabupaten Polewali Mandar. Adapun data yang diperoleh dalam penelitian ini bersumber pada data observasi, wawancara, studi pustaka, dan dokmentasi. Observasi merupakan suatu cara mengumpulkan data dengan jalan mengadakan pengamatan terhadap kegiatan yang sedang berlangsung. Wawancara adalah suatau proses tanya jawab lisan, dimana 2 orang atau lebih saling berhadapan secara fisik, yang satu dapat melihat muka lain dan mendengar dengan telinga sendiri dari suaranya (Sukandarrumidi, 2006). Studi pustaka adalah kumpulan data yang dilakukan dengan mencari sumber data tertulis seperti buku, artikel jurnal dan laporan penelitian terdahulu yang dapat dijadikan landasan teori untuk memperkuat proses analisis data. Dokumentasi adalah pengumpulan data yang mengandung informasi dari objek penelitian agar dapat membantu peneliti, baik dari sumber yang berbentuk tulisan seperti kebijakan, catatan harian, atau sumber-sumber yang berbentuk gambar seperti foto dan lain-lain.

\section{HASIL PENELITIAN}

Dinas Kesehatan ini resmi terbentuk sejak pada tahun 1960 dengan dasar Undang-Undang nomor 29 tahun 1959 tentang pembentukan daerah tingkat II di Sulawesi, dan Undang-Undang nomor 29 tahun 1960 tentang 
pokok-pokok pemerintahan. Awal terbentuknya mempunyai wilayah kerja yang cukup luas yaitu wilayah Polewali dan Mamasa yang dulu disebut sebagai Kabupaten Polewali Mamasa, dalam perkembanganya yaitu ditahun 2002 berdasarkan Undang-Undang nomor 11 tentang pembentukan Kabupaten Mamasa, wilayah Mamasa resmi menjadi Satu Kabupaten, sehingga Kabupaten Polewali Mamasa berganti nama menjadi Kabupaten Polewali Mandar. Dan kemudian berdasarkan Undang-Undang nomo 26 tahun 2004 tentang pembentukan Propinsi Sulawesi Barat, wilayah ini (Kab. Polewali Mandar, Mamasa, Majene, Mamuju dan Mamuju Utara) resmi menjadi satu Propinsi berpisah dengan propinsi Sulawesi Selatan. Awalnya kantor Dinas Kesehatan bergabung dengan Kantor Pemerintah Kabupaten Polewali Mamasa (Tempo Doelue) ini beralamat di Jalan Basiru Nomor 1 Polewali, sekarang diawal tahun 2008 gedung ini menjadi kantor Kelurahan Polewali Kecamatan Polewali. 20 tahunsebelumnya yaitu tepatnya ditahun 1980an Karena Pemerintah Kabupaten

Polewali Mamasa Membangun Gedung Baru Rumah Sakit Umum Daerah (RSUD Polewali) dan meninggalkan gedung lamanya yang masih layak pakai, Kantor Dinas Kesehatan menempati gedung Rumah Sakit ini hingga sekarang. Sementara Gedung yang lama Pemda Polewali Mamasa ditinggalkan Pemda Polmas dengan Gedung Barunya, Gedung Lama penda cq Dinas Kesehatan ditempati sementara oleh dr. H. Atjo Manaf, sebagai rumah jabatan Kepala Dinas Kesehatan waktu itu.

Pada tahun 2005 Dinas Kesehatan Kabupaten Polewali Mandar melepas salah satu UPTnya (Unit Pelaksana Tehnisnya) RSUD Polewali menjadi Kantor dan bertanggung jawab secara langsung kepada Kepala Daerah (Bupati). Masih dalam tahun yang sama Dinas Kesehatan Polewali Mandar kemudian di merger dengan BKKBN sebagai konsekwensi di dekonsentrasikan BKKBN oleh Pemerintah pusat dan lemahnya posisi strategis Dinas Kesehatan pada awal-awal desentralisasi. Namun di sayangkan pada tahun 2008 sebagai konsekwensi dari penerapan Kepres no 41 tahun 2007 tentang Organisasi Perangkat Daerah. BKKBN Kabupaten Polewali Mandar harus dipisahkan lagi dengan Dinas Kesehatan.

Sejak melepas UPTnya RSUD Polewali dan merjer dengan BKKBN dengan nama Dinas Kesehatan dan KB, mempunyai kedudukan Sesuai SK Bupati nomor 14 tahun 2006 disebutkan bahwa kedudukan dari Dinas Kesehatan dan keluarga Berencana merupakan unsur pelaksaksana Pemerintah Kabupaten di bidang kesehatan dan keluarga berencana. Dinas di pimpin oleh seorang kepala yang berada di bawah dan bertanggung jawab kepada Bupati melalui Sekretaris Daerah. Dua tahun merger pembangunan kesehatan dan keluarga berencana bergerak dengan cepat, menjadikan indikator Indonesia sehat sebagai target Kabupaten sehat, hal ini ditandai dengan diterimanya 
penghargaan dari Presiden Republik Indonesia "Manggala Karya Bakti Husada" sebagai penghargaan tertinggi dalam pembangunan kesehatan dan pengharggaan "Manggala Karya Kencana" sebagai penghargaan tertinggi dalam pembangunan keluarga berencana.

Perpisahan dua instansi yang sebelumnya dalam posisi yang lemah dan bergabung menjadi kekuatan besar guna mempercepat pembangunan kesehatan, kependudukan dan keluarga berencana, membuat masing-masing dinas harus merombak kembali visinya. Dimana visi sebelumnya adalah terwujudnya kemandirian sehat dan kemandirian keluarga pada masyarakat Polewali Mandar berdasarkan agama dan nilai-nilai budaya. Makna dari Visi tersebut diatas adalah gambaran komitmen dari dinas kesehatan dan keluaraga berencana beserta seluruh jajarannya yang lebih mengupayakan kemandirian sehat dan kemandirian keluarga pada masyarakat dalam menangani persoalan kesehatan dan keluarga berencana sesuai dengan agama dan nilai-nilai budaya 'Sipamandar 'Diawal Desentralisasi Visi ini dibuat dan dirancang untuk dapat dicapai ditahun 2005, yaitu Terwujudnya kemandirian sehat pada masyarakat Polewali Mandar berdasarkan agama dan nilai-nilai budaya. Namun setelah di merger dengan BKKBN dan karena kompleksitas permasalahan kesehatan dan keluarga berencana yang dihadapi begitu besar dan rumit, maka sejak tahun 2006 kemandirian sehat ditambahan dengan kemandirian keluarga dan penentuan batas waktu dihilangkan, Namun demikian tidak dicantumkannya batas waktu ini tidak berarti berubah makna yang terkandung di dalamnya. demikian juga dengan penambahan kemandirian keluarga sebagai penyesuaian dari visi BKKBN pusat yaitu Seluruh Keluarga Ikut KB yang dapat diartikan adanya kemandirian keluarga untuk ber KB merupakan konsekwensi dari di mergernya.

\section{Tupoksi Dinas Kesehatan}

Tupoksi Peraturan Bupati Kabupaten Polewali Mandar Nomor 39 Tahun 2007 tentang tupoksi Dinas Kesehatan. Yaitu dengan tupoksi Dinas Kesehatan Kabupaten Polewali Mandar Dinas Kesehatan mempunyai tugas membantu Bupati melaksanakan urusan Pemerintahan di bidang kesehatan yang menjadi wewenang daerah dan tugas pembantuan yang diberikan kepada kabupaten, yang terbagi dan terinci secara sistematis ke dalam tugas sekertaris, yang terbagi masing-masing bidang, subbagian dan seksi.

a. Dinas mempunyai tugas membantu bupati melaksanakan urusan pemerintahan di bidang kesehatan yang menjadi kewenangan daerah dan tugas pembantuan yang diberikan kepada kabupaten, yang terbagi dan terinci secara sistematis ke dalam tugas sekretaris,masing-masingbidang, subbagian dan seksi. 
b. Sekretariat dinas mempunyai tugas menyelenggarakan urusan umum,kepegawaian, perlengkapan, pengelolaan keuangan, penyusunan program, evaluasi dan pelaporan dinas yang terbagi dan terinci secara sistematis ke dalam tugas masing-masing subbagian.

c. Subbagian keuangan dan perlengkapan mempunyai tugas melaksanakan pengelolaan administrasi keuangan dan perlengkapan dinas.

d. Subbagian umum dan kepegawaian mempunyai tugas melaksanakan urusan umum dan kepegawaian dinas.

e. Subbagian penyusunan program, evaluasi dan pelaporan mempunyai tugas melaksanakan kegiatan penyusunan program, evaluasi dan pelaporan.

f. Bidang pelayanan kesehatanmempunyai tugas merumuskan dan melaksanakan kebijakan di bidang pelayanan kesehatan, yang terbagi dan terinci secara sistematis ke dalam tugas masing-masing seksi.

g. Seksi pelayanan kesehatan primer dan tradisional mempunyai tugas melaksanakan penyiapan bahan perumusan kebijakan dan fasilitasi serta evaluasi pelaksanaan pelayanan kesehatan primer dan tradisional.

h. Seksi pelayanan kesehatan rujukan dan penjaminan kesehatan mempunyai tugas melaksanakan penyiapan bahan perumusan kebijakan dan fasilitasi serta evaluasi pelaksanaan pelayanan kesehatan rujukan dan penjaminan kesehatan.

i. Seksi mutu pelayanan kesehatan mempunyai tugas melaksanakan penyiapan bahan perumusan kebijakan dan fasilitasi serta evaluasi pelaksanaan mutu pelayanan kesehatan.

j. Bidang kesehatan masyarakat mempunyai tugas merumuskan dan melaksanakan kebijakan di bidang kesehatan masyarakat, yang terbagi dan terinci secara sistematis ke dalam tugas masing-masing seksi.

k. Seksi kesehatan keluarga dan gizi mempunyai tugas melaksanakan penyiapan bahan perumusan kebijakan dan fasilitasi serta evaluasi pelaksanaan kegiatan kesehatan keluarga dan gizi.

1. Seksi promosi kesehatan dan pemberdayaan masyarakat mempunyai tugas melaksanakan penyiapan bahan perumusan kebijakan dan fasilitasi serta evaluasi pelaksanaan kegiatan promosi kesehatan dan pemberdayaan masyarakat.

m. Seksi penyehatan lingkungan, kesehatan kerja dan olah raga mempunyai tugas melaksanakan penyiapan bahan perumusan kebijakan dan fasilitasi serta evaluasi pelaksanaan kegiatan penyehatan lingkungan dan kesehatan kerja.

n. Bidang pencegahan dan pengendalian penyakit mempunyai tugas merumuskan dan melaksanakan kebijakan di bidang pencegahan dan pengendalian penyakit, yang terbagi dan terinci secara sistematis ke dalam tugas masing-masing seksi. 
o. Seksi surveilans dan imunisasi mempunyai tugas melaksanakan penyiapan bahan perumusan kebijakan dan fasilitasi serta evaluasi pelaksanaan kegiatan surveilans dan imunisasi.

p. Seksi pencegahan dan pengendalian penyakit menular mempunyai tugas melaksanakan penyiapan bahan perumusan kebijakan dan fasilitasi serta evaluasi pelaksanaan kegiatan pencegahan dan pengendalian penyakit menular.

q. Seksi pengendalian penyakit tidak menular dan kesehatan jiwa mempunyai tugas melaksanakan penyiapan bahan perumusan kebijakan dan fasilitasi serta evaluasi pelaksanaan kegiatan pengendalian peksi kefarmasian mempunyai tugas melaksanakan penyiapan bahan perumusan kebijakan dan fasilitasi serta evaluasi pelaksanaan kegiatan kefarmasian.enyakit tidak menular dan kesehatan jiwa.

r. Bidang sumber daya kesehatan mempunyai tugas merumuskan dan melaksanakan kebijakan di bidang sumber daya kesehatan, yang terbagi dan terinci secara sistematis ke dalam tugas masing-masing seksi.

s. Seksi fasilitas pelayanan kesehatan mempunyai tugas melaksanakan penyiapan bahan perumusan kebijakan dan fasilitasi serta evaluasi pelaksanaan kegiatan pengelolaan fasilitas pelayanan kesehatan.

t. Seksi pengembangan sumber daya manusia kesehatan mempunyai tugas melaksanakan penyiapan bahan perumusan kebijakan dan fasilitasi serta evaluasi pelaksanaan kegiatan pengembangan sumber daya manusia kesehatan.

u. Kelompok jabatan fungsional sebagaimana dimaksud, mempunyai tugas melaksanakan sebagian tugas dinas sesuai dengan kebutuhan.

Pengembangan karir dalam hal ini di kerucutkan hanya dengan ruang lingkup Dinas Kesehatan yang mana menjadi rumusan masalah yaitu pengembangan karir di dalam aturan yang berlaku yang mengatur segalah aspek kepegawaian di ruang lingkup Dinas Kesehatan. Dalam membahas pengembangan karir tak lepas daripada sumber daya pegawainya dalam hal ini yaitu potensi dikembangkan menuju karir yang selanjutnya, membidik target dengan menyesuaikan jenjang pendidikan dan pangkat tersebut dan memperhatikan permintaan atau rekomendasi dari instansi tersebut sesuai dengan jabatan yang menjadi target tersebut. Dalam manajemen birokrasi Dinas Kesehatan Kabupaten Polewali Mandar telah dilaksankan dalam proses mengikuti peraturan yang berlaku salah satu Undang-undang Nomor 5 Tahun 2014 yang mengatur tentang ASN terdapat yang mengatuur tentanng pengembangan karir.

Dalam mengikuti langkah pengembangan karir ialah harus memenhi aspek berikut ialah dengan memahami kemampuan diri sendiri dalam bidang yang akan di tempuh, adanya tujuan karir setelah pengembangan tersebut, dan 
melaksanakan rencan dan syarat yang harus dipenuhi oleh lembaga tersebut yang terkait. Karir adalah urutan, status, jenjang dan pengalaman pekerjaan, jabatan atau posisi seseorang baik dalam perusahaan, organisasi maupun pekerjaan sehingga menuntut tanggung jawab dan kemampuan kerja yang lebih baik.

Karir juga dapat diartikan sebagai rangkaian aktivitas pekerjaan berkelanjutan dan melibatkan pilihan dari berbagai macam kesempatan yang terjadi akibat interaksi individu dengan organisasi dan lingkungan sosialnya. Sumber daya merupakan hal yang utama dalam suatu roda pemerintahan, pengelolaan suatu lembaga ataupun mengelola suatu masyarakat adalah bermodalkan suatu sumber daya manusia dalam hal ini ialah pegawai.

Sebagai spesialis fungsional yang mempunyai kemampuan berfikir menilai dan memecahkan masalah yang dihadapi secara konsepsional dan komperhensif di lingkungan organisasi/departemennya.Pengembangan karir. Dalam rangka mewujudkan sistem pemerintahan yang bersih dan berwibawa (good gavernance) serta mewujudkan pelayanan publik yang baik, efisien, efektif dan berkualitas tentunya perlu didukung adanya Sumber Daya Manusia aparatur khususnya Pegawai Negeri Sipil yang profesional, bertanggungjawab, adil, jujur dan kompeten dalam bidangnya. Dengan kata lain, PNS dalam menjalankan tugas tentunya harus berdasarkan pada profesionalisme dan kompetensi sesuai kualifikasi bidang ilmu yang dimilikinya.

Berkaca kepada permintaan instansi dalam hal ini bahwa kouta mengikuti pengembangan karir tak semerta-merta haruslah sesuai permintaan semisal apabila ada yang pensiun atau meninggal dunia peluang pengembangan sangatlah besar dengan ditinjau dari kemampuan yang memadai dan menyesuaikan pangkat terhadap kinerja Penempatan dalam rangka Pengembangan Profesi Dari penggabungan antara bakat dan minat pegawai, dapat diarahkan untuk diberi tugas dalam jabatan-jabatan yang memerlukan syarat kualifikasi teknis dan kemampuan mengenal kegiatan-kegiatan manajemen. Pengawasan pada tahap ini dikombinasikan dengan pelatihanpelatihan teknik sosialisasi dan teknik manajemen pada tingkat dasar, yaitu :

Penugasan dalam rangka Pemantapan Profesi Dalam tahap ini secara selektif pegawai ditugasi:

a. Sebagai manajer staf dan manajer lainnya sesuai dengan kemampuannya guna memantapkan kemampuan manajerialnya yang bersangkutan agar dapat meniti jenjang jabatan yang lebih tinggi.

b. Sebagai spesialis sesuai dengan keahliannya untuk dapat mengenali, menilai dan memecahkan setiap masalah dalam lingkup tugasnya, dalam konteks keseluruhan, masalah yang dihadapi oleh organisasi. 


\section{KESIMPULAN}

Bahwa dengan berlandaskan Undang-undang Nomor 5 Tahun 2014 tentang ASN. Yang dalam kandungannya mengatur tentang pengembangan karir yang mana sudah dalam tahap yang sesuai dengan pemberdayaan ASN di Dinas Kesehatan dengan memperhatikan pegawainya terhadap pengembangan karir tersebut denagan upaya memperhatikan kedisiplinan, jenjang pendidikan dan rekomendasi dari instansi setempat. Bahwasanya dalam pengelolaan tersebut sudah telah berjalan dengan cukup baik berdasarkan peraturan yang berlaku dengan tetap mengedepankan kedisiplinaan dan prilaku ASN tersebut. Hanya saja dalam hal ini persoalan mengenai data daripada yang di dapatkan di lokasi penelitian masih banyak yang kurang diperbarui sekiranya itu adalah bahan dalam perbaikan pengelolaan roda organisasi tersebut.

\section{SARAN}

Saran terlebih kepada seluruh elemen masyarakat menjalankan segalah aktifitas dan pekerjaan dengan tidak melanggar peraturan dan norma-norma yang berlaku dengan senantiasa menjaga keharmonisan berlembaga. pengembangan karir dan promosi jabatan atau dalam hal ini kepada pegawai atau pemangku jabatan raihlah pengembangan dengan selalu berasaskan aturan yang berlaku dan selalu mengalamatkan pengembangan kepada kemajuan daerah yang kita cintai ini.

\section{DAFTAR PUSTAKA}

Achmad, S. Ruky. 2006. Sistem Manajemen Kenerja, Jakarta, PT. Gramedia Pustaka.

Danang, Sunyoto. 2012. Manajemen Sumber Daya Manusia, Jakarta, PT. Buku Seru.

Flippo, Edwin. 1997. Manajemen Personalia, Jakarta, PT. Erlangga

George R. Terry. 2005. Principles of Management, New York, Alexander Hamilton Institute.

Handoko, T. Hani. 2012. Manajemen Personalia dan Sumber Daya Manusia. Yogyakarta: BPFE.

Marwansyah. 2012. Manajemen Sumber Daya Manusia, Bandung, Alfabeta

Undang-undang No 5 Tahun 2014 tentang ASN

Undang-undang Nomor 25 tahun 2009 tentang Pelayanan Publik 
Undang-undang 29 Tahun 1959 tentang Pembentukan Daerah Tingkat Ll Di Sulawesi

Undang-undang Nomor 29 Tahun 1960 tentang Pokok-Pokok Pemerintahan

Undang-undang Nomor 26 Tahun 2004 tentang Pembentukan Provinsi Sulawesi Barat 